TI 2016-098/VIII

Tinbergen Institute Discussion Paper

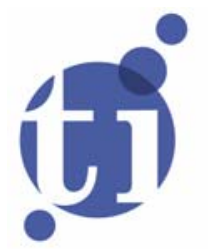

\title{
Financial Globalization and Foreign Direct Investment
}

Steven Poelhekke

Faculty of Economics and Business Administration, VU University Amsterdam, and Tinbergen Institute, The Netherlands. 
Tinbergen Institute is the graduate school and research institute in economics of Erasmus University Rotterdam, the University of Amsterdam and VU University Amsterdam.

More TI discussion papers can be downloaded at http://www.tinbergen.nl

Tinbergen Institute has two locations:

Tinbergen Institute Amsterdam

Gustav Mahlerplein 117

1082 MS Amsterdam

The Netherlands

Tel.: +31(0)20525 1600

Tinbergen Institute Rotterdam

Burg. Oudlaan 50

3062 PA Rotterdam

The Netherlands

Tel.: +31(0)10 4088900

Fax: +31(0)10 4089031 
Entry for Encyclopaedia of International Economics and Global Trade

\title{
Financial Globalization and Foreign Direct Investment
}

\author{
Steven Poelhekke* \\ Vrije Universiteit Amsterdam, De Nederlandsche Bank, and Tinbergen Institute
}

20 October 2016

\begin{abstract}
This chapter provides a broad overview of the upward trends in financial globalization and foreign direct investment and asks whether and how financial globalization is linked with the foreign direct investment decisions of non-financial multinational enterprises. Several potential links and their empirical support in the recent literature are discussed: the elements of foreign direct investment that require (global) financial services; the role of trade credit; and the question whether banks follow their customers abroad. Finally, the effect of the recent financial crisis is discussed. It finds that financial globalization provides a reduction in broadly defined transaction costs which can boost both trade and foreign direct investment, at the costs of more exposure of the real economy to financial shocks.
\end{abstract}

Key words: foreign direct investment, financial globalization, banks.

JEL Classification: F23, F36, F43, 040.

* Vrije Universiteit Amsterdam, Tinbergen Institute, CESifo, and De Nederlandsche Bank. Contact information: Vrije Universiteit Amsterdam, Faculty of Economics and Business Administration, De Boelelaan 1105, 1081 HV Amsterdam, The Netherlands. Email: steven.poelhekke@vu.nl. The views expressed are those of the author and do not necessarily reflect official positions of De Nederlandsche Bank. 


\section{Introduction}

The World has experience a substantial increase in financial globalization - defined as a rise in the number and value of investments done in an increasing number of foreign countries other than the investor's home country. This trend picked up speed in particular since the 1990s but came to a standstill during the recent global financial crisis. While in 1970 the ratio of total gross foreign assets to GDP was only 0.25 , it had risen to 1.72 by 2011 (see Figure 1). This suggests that the size of the global financial system has increased almost seven-fold during a period of 40 years.

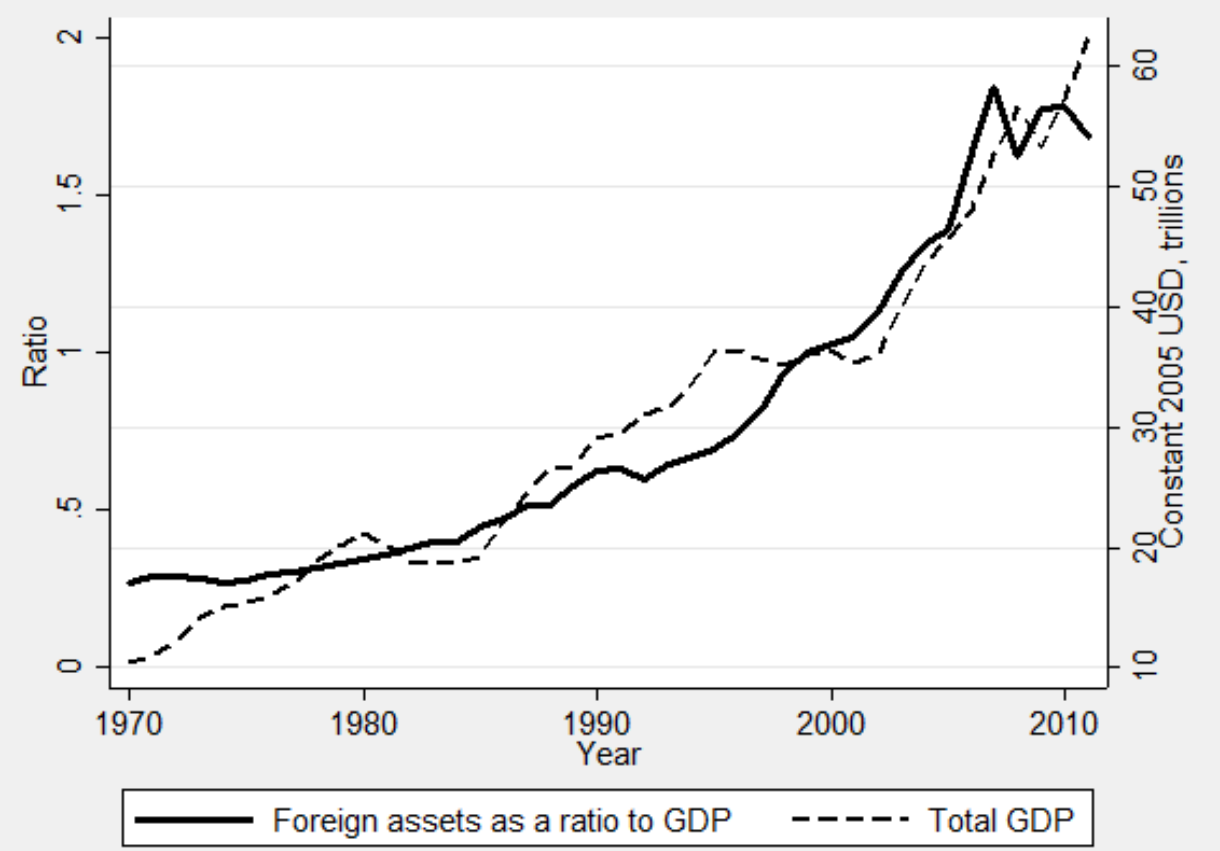

Figure 1: Financial Globalization and World GDP

(stocks of 86 countries for which data is available since 1970; source: updated and extended version of dataset constructed by Lane and Milesi-Ferretti (2007) and World Bank's World

Development Indicators 2013)

It is widely accepted that this wave of international financial integration was the result of liberalization of capital controls - the deregulation of domestic financial systems after a period of low openness and high regulation that started with the advent of World War I - and a more recent technological revolution that includes financial innovations and improvements in 
the flow of information and telecommunication (Caprio, 2012). The degree and scope of integration varies. While almost all countries participate in this global market today, it is still the case that investors tend to invest relatively close to home, which gives a somewhat more regional flavor to financial globalization (Coeurdacier and Rey, 2012). The degree of integration also varies by continent, with the bulk of cross-border investment taking place among developed countries. In particular, the strongest bilateral links by volume are between the UK and the euro area and between the US and Caribbean offshore centers (McGuire and Tarashev, 2008). It also does not necessarily imply that domestic capital markets have deepened: on the one hand, Asian countries are relatively well integrated despite the Asian crisis of the late 1990s, while Latin America and Africa on the other hand lag behind (De la Torre et al., 2008). Finally, it has also been accompanied by 'global imbalances' or substantial current and capital account deficits and surpluses (see Chinn et al., 2014).

These trends pose benefits and risks to both developed and developing countries. On the one hand, financial globalization can open countries to adverse foreign shocks through contagion and sudden capital flow reversals, which may make countries more vulnerable to crises. Debt flows for example are considered risky, procyclical and highly volatile. The recent financial crisis is a clear example of these risks, and it has resulted in a call for and the implementation of more regulation. On the other hand, countries now have a greater supply of external financing available at lower costs, more diverse financial instruments, and higher quality financial services allow for better financial intermediation and risk diversification. A better allocation of resources, which often comes about through technological improvements through the entry of foreign banks (Goldberg, 2009), may allow higher global growth, although there is no conclusive empirical evidence on the positive effect of financial globalization on growth as surveyed by Kose et al. (2009) and Obstfeld (2009). There is stronger evidence for a positive relationship between domestic financial development and economic growth (Levine, 2005) but the recent literature has also emphasized the non-linearity between financial development and economic growth (e.g. Arcand et al., 2015). More established is the fact that foreign capital, especially in the form of relatively stable foreign direct investment (FDI) as opposed to more volatile debt or portfolio equity flows, can result in the import of knowledge 
and technology which helps countries catch up to the technological frontier. FDI is particularly useful because it affects productivity growth positively (Javorcik, 2004; Guadalupe et al., 2012; Javorcik and Poelhekke, 2016), with the qualification that at the macro level it seems to depend on human capital (Borensztein et al. 1998) and deep financial markets (Alfaro et al., 2004; Javorcik and Spatareanu, 2009).

Foreign direct investment (FDI) and overall financial globalization have followed a similar global trend as Figure 2 shows. By 2011, FDI represented a value of 16 trillion dollars, even though as a share of all foreign assets, FDI has relatively declined from representing $44 \%$ of total foreign assets in 1970 to $19 \%$ by $2011 .{ }^{1}$ The available data shows that, by now, 153 countries hold FDI assets in 183 countries.

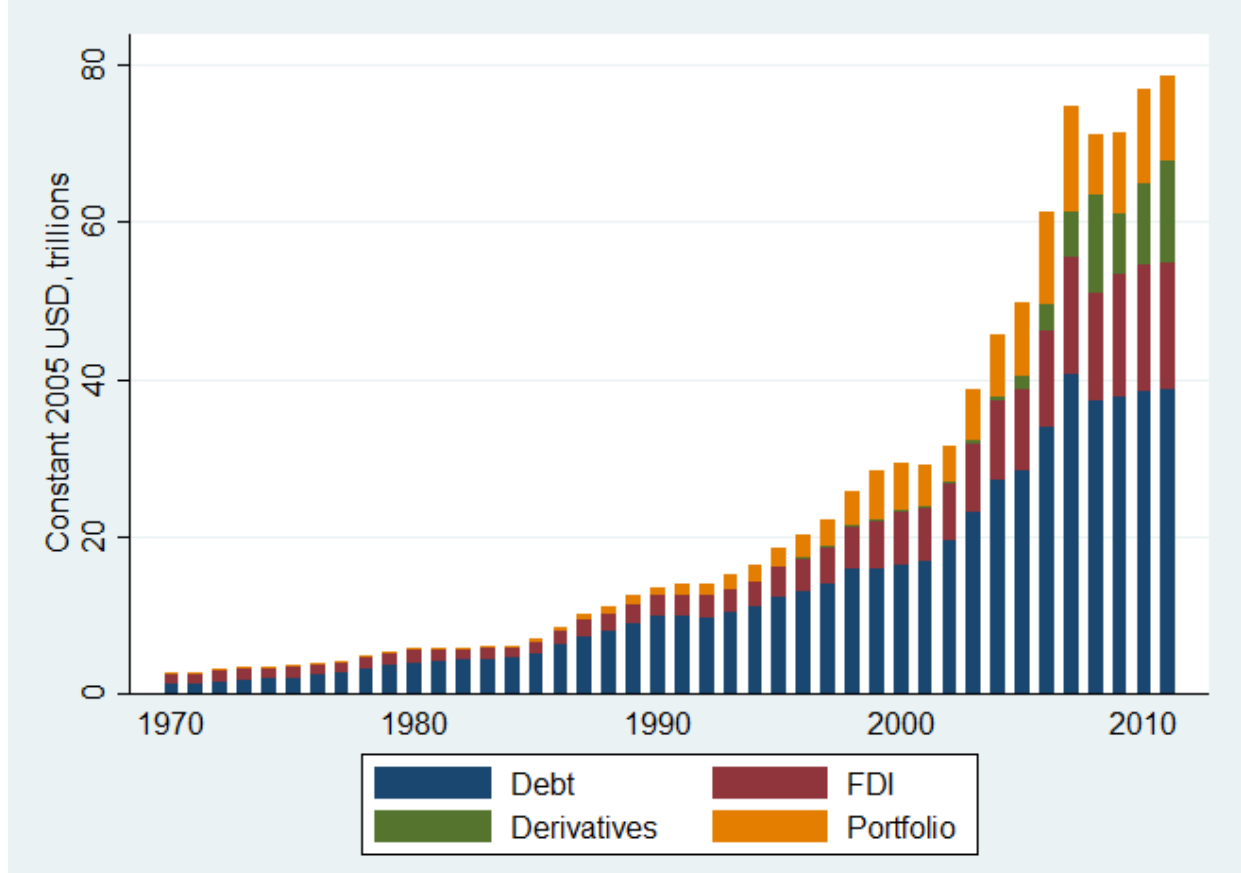

Figure 2: Foreign assets by category

(stocks of 86 countries for which data is available since 1970; source: updated and extended version of dataset constructed by Lane and Milesi-Ferretti (2007) and World Bank's World Development Indicators 2013)

\footnotetext{
${ }^{1}$ This trend still holds if all countries are included. FDI then represents a value of 22 trillion dollars and $21 \%$ of total assets.
} 
This chapter provides a broad overview of the trends in financial globalization and foreign direct investment and asks whether and how financial globalization is linked with the foreign direct investment decisions of non-financial multinational enterprises (MNEs), motivated by the perceived direct real benefits of this form of capital flow. It views FDI as potentially being influenced directly by the integration of financial markets and the growth of multinational banking in particular. ${ }^{2}$ Several potential links and their empirical support in the recent literature are discussed: the elements of foreign direct investment that require (global) financial services; the role of trade credit; and the question whether banks follow their customers abroad. Finally, the effect of the recent financial crisis is discussed. It finds that financial globalization provides a reduction in broadly defined transaction costs which can boost trade and foreign direct investment, at the costs of more exposure of the real economy to financial shocks.

The rest of this chapter is organized as follows. Section 2 describes the pattern of financial sector deregulation in more detail and the effect that it has had on the rise of global banking. Section 3 briefly reviews the motives for firms to pursue FDI and highlights the role of transaction costs and links financial globalization and multinational banking to a reduction in transaction costs. Section 4 discusses the effect of the recent financial crisis and Section 5 concludes.

\footnotetext{
2 The banking literature has mostly focused on the impact of foreign banks on domestic financial development, the propagation of shocks and access to finance for domestic firms. See Cull and Martinez Peria (2010) for a survey.
} 


\section{Deregulation, banking globalization and FDI}

The deregulation of the global financial system that accompanied the increase in financial globalization is made visible by an IMF database on financial reform (Abiad et al., 2010). The database tracks policy changes in 91 countries between 1973 and 2005 on several dimensions. The main index is the sum of credit controls and reserve requirements, credit ceilings, interest rates, banking sector entry, capital account transactions, privatization of banks, security markets and banking sector supervision, which are each measured in integer steps from zero to three, where three is fully liberalized. Figure 3 tracks the main index for six groups of countries and shows that advanced economies have always been the most liberal countries. All other regions, and especially Latin America and former communist countries, have undergone tremendous reforms. The average increased from a low of 3 to a high of 16 on a scale of 21 by the year 2005 . Figure 4 shows the evolution of one such dimension, the barriers to entry in the banking sector. It is composed of majority foreign ownership of domestic banks, free entry of new domestic banks, no branching restrictions, and allowing universal banks. The banking sector was up until the $80 \mathrm{~s}$ and 90 s one of the most widely regulated sectors, with common state ownership, entry restrictions, and capital flow and interest rate regulations. By 2005 however, the advanced economies reached the highest level of liberalization of the banking sector with Emerging Asia (incl. China) trailing the other regions at only $20 \%$ below full liberalization. $^{3}$

\footnotetext{
${ }^{3}$ In Figures 3 and 4 SSA refers to Sub-Saharan Africa and MENA to the Middle East and North Africa.
} 


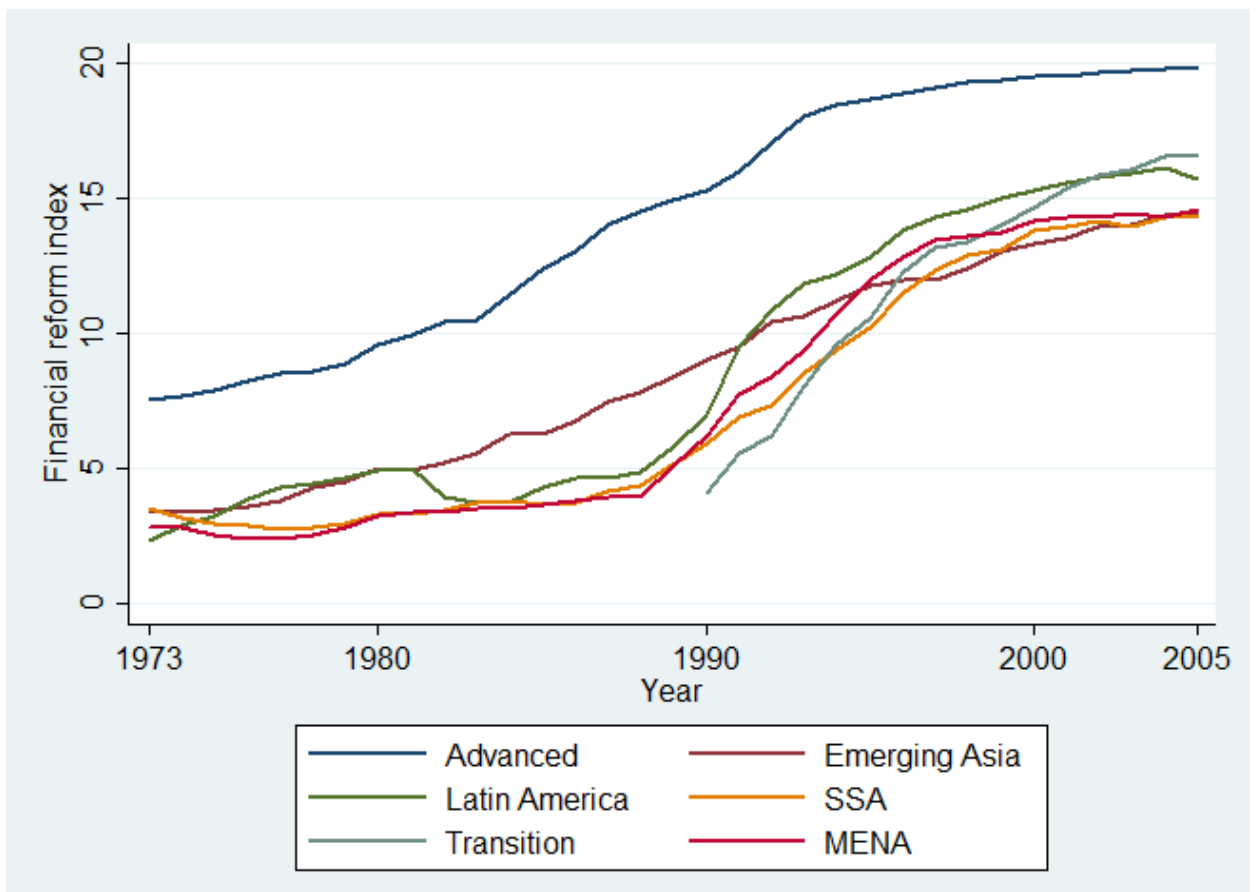

Figure 3: Financial reform by region

(Source: Abiad et al., 2010)

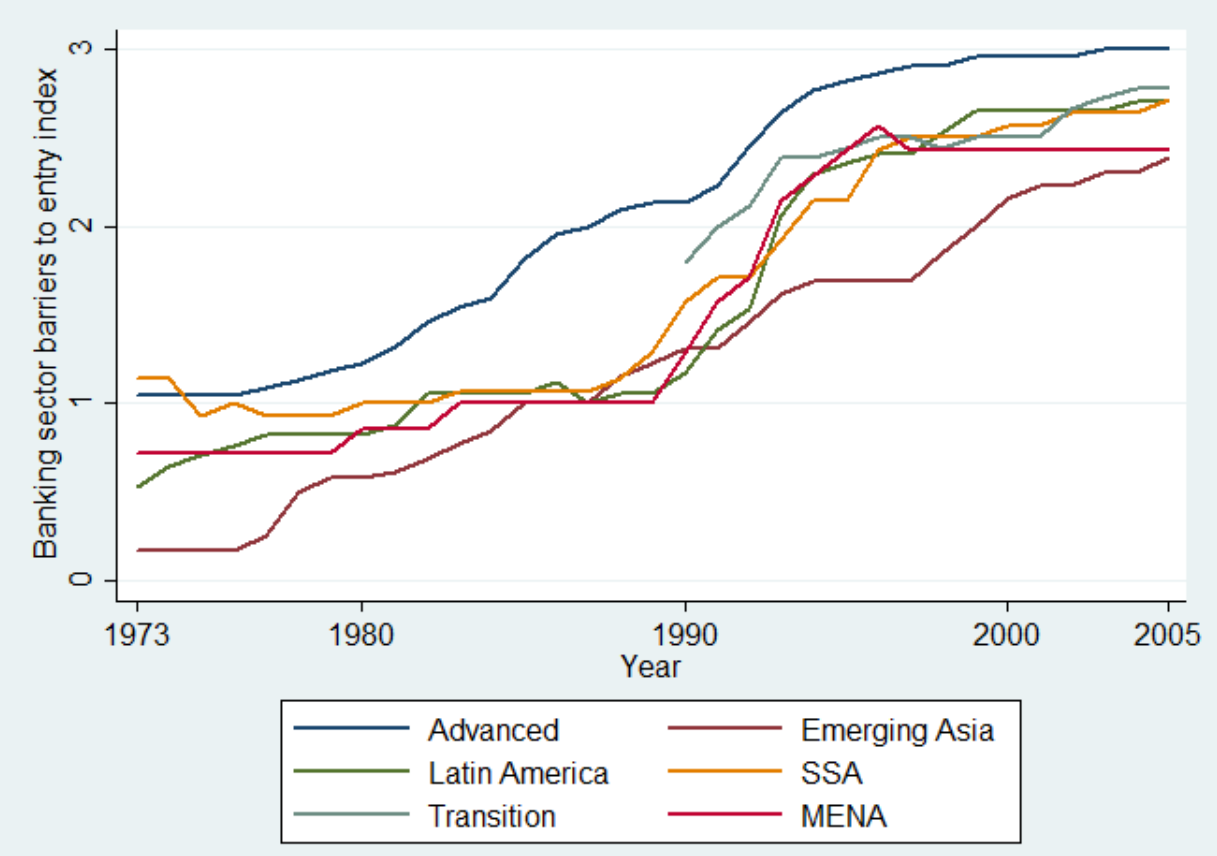

Figure 4: Reform of banking sector barriers to entry

(Source: Abiad et al., 2010) 
This decrease in regulation contributed to the creation of some of the world's largest banking groups. In the United States, the repeal of the Glass-Steagall Act in 1999, which restricted equity financing and separated investment banks from commercial banks, and the staggered lifting of intra-state branching and interstate banking restrictions from 1994 onwards, triggered a wave of mergers; as did the introduction of the euro in Europe in 1999. The decrease in entry restrictions has promoted the internationalization of banks according to Goldberg and Grosse (1994). This also resulted in the creation of universal banks which blurs bank and nonbank financial services such as retail banking and insuring. This has come at the risk of abuse of market power and moral hazard issues, such as when institutions are considered to be too big to fail or systemic to the whole system (Strahan, 2013). As a result of the vulnerabilities that the recent financial crisis exposed, the degree of regulation has increased again in recent years, for example through the creation of a banking union ${ }^{4}$ in Europe and the enhanced agreements by the Basel Committee on Banking and Supervision on capital requirements, or through outright (political) pressure on banks to reduce foreign exposures (Rose and Wieladek, 2014).

Overall, the trend in liberalization has led to the internationalization of banks. Where manufacturing firms internationalize through trade and/or foreign direct investment in the form of mergers and acquisitions or greenfield foreign investment, banks can do so in multiple ways. Banks can lend across borders directly, set up foreign branches, or acquire foreign subsidiaries. They can also lend abroad as a consortium of banks, which is called syndicated lending. Finally, by simply buying foreign assets such as treasury bills and securitized assets traded on markets they can supply capital to destination markets indirectly. Several papers and datasets shed light on the international activities of banks. For example, Buch et al. (2011) report that out of all 2,226 German banks, observed between 2002 and 2006, only 11\% lend in

\footnotetext{
${ }^{4}$ The banking union is a transfer of responsibility for banking policy from the national to the EU level. This is meant to prevent policy competition between national supervisory authorities in times of crisis. Euro zone countries and several other countries have joined. This has given the ECB direct supervisory power and a common set of rules (the Single Supervisory Mechanism) for the largest banks in Europe and indirect, via cooperation with national supervisory authorities, over smaller banks. Secondly, there is also a proposal for a Single Resolution Mechanism that specifies how troubled banks can be supported or restructured in times of crisis which will facilitate swift decision making.
} 
the domestic market alone, while the remainder lends across borders to 63 different destination countries. $99 \%$ of banks hold foreign assets if foreign treasury bills are also included. However, only a small fraction, 37 banks in total, operates foreign branches and/or subsidiaries and they do so in only 3 destination countries per bank on average, despite the wave of liberalizations. Setting up these foreign operations entails high fixed costs, much like the fixed costs associated with FDI performed by manufacturing firms, except that in this case they relate also to capital and regulatory requirements (Cerutti et al., 2007). It nevertheless increases profitability for the (larger) banks that operate in this way, because it reduces screening costs and allows more relationship lending. The latter shows up in Belgian data where borrowers that are located close to the branch where they received their loan (but far from alternative competing branches) pay significantly higher loan rates (Degryse and Ongena, 2005). There is however considerable heterogeneity across source countries: Dutch data shows that Dutch banks held FDI in almost 60 countries in 2002 (Poelhekke, 2015), up from less than 40 in 1984. Publicly available data on US FDI stocks abroad on deposit taking banks from the Bureau of Economic Analysis suggest that these US banks held FDI in 40 countries in 1998. By 2015 this number had increased to 89 countries. ${ }^{5}$ According to Buch and Lipponer (2007) this may be directly related to the heterogeneity in productivity of banks themselves, leading to selection into different forms of internationalization much like the process by which MNEs internationalize.

Data on syndicated loans, which are large loans or credit lines financed by capital pooled from a group of banks (which thus share risk), shed light on the global network of banks (Hale, 2012). These loans can be extended to firms, but are also commonly extended to other banks in need of liquidity. The latter types of syndicated loans suggest a dense network of banks, in which banks from 60 countries were involved in 1980 and from 81 countries in 2009. The median maturity of these loans is 3 years which suggests that they likely create substantial information flows between banks and reduce information asymmetry. Recessions and banking

\footnotetext{
${ }^{5}$ Author's calculation. See http://www.bea.gov/international/. Unfortunately, the publicly available BEA data includes entries $\left(^{*}\right)$ and (D), which respectively stand for "a non-zero value between $-500,000$ and $+500,000$ " dollars. These data have been suppressed to avoid disclosure of data of individual companies. There is a break in the data in 1999.
} 
crises have a negative effect on the formation of these ties which in turn decreases loan supply in subsequent years.

The BIS collects data on cross-border lending by reporting-country and destination (on the basis of the ultimate risk can be traced to a specific bank), which makes it possible to measure interbank exposures. ${ }^{6}$ As of 2005, foreign claims represented less than $20 \%$ of US, Australian and Italian banks' total balance sheet assets, but 50\% for UK and Belgian banks, and $60 \%$ for Swiss banks. $84 \%$ of all foreign claims were vis-à-vis developed countries. A third of foreign claims are on other banks, half on the non-bank private sector and the remainder is lent to the public sector (McGuire and Tarashev, 2008). ${ }^{7}$

Another data source on international banking comes from Bureau van Dijk's Bankscope. Micco et al. (2007) show that for banks in 179 countries observed between 1995-2002, the share of assets that was foreign owned increased from 20\% in 1995 to 32\% in 2002, while the share of government owned banks decreased from $30 \%$ in 1995 to $18 \%$ in 2002 . Where domestic banks tend to be most profitable in developed countries, it is the foreign banks that are most profitable in developing countries. The largest share of foreign banks can be found in Sub-Saharan Africa, the Caribbean, Eastern Europe, Central Asia, and Latin America. Claessens and Van Horen (2015) have updated this data to 2013 and show that the share that was foreign owned increased only somewhat further, to $34 \%$ in 2013. The share of foreign banks has increased the most in Sub-Saharan Africa. ${ }^{8}$

The picture that emerges is that financial institutions not only hold more and more assets in an increasing number of countries, but also that they have internationalized themselves by setting up operations or acquiring subsidiaries in foreign countries. Banks have increasingly become multinational enterprises themselves.

\footnotetext{
${ }^{6}$ See: http://www.bis.org/statistics/bankstats.htm.

${ }^{7}$ The drawback of this data is however that not all countries report to the BIS (although the number is increasing over time) and there are frequent breaks in the time series. See: http://www.bis.org/statistics/breakstables17.pdf and http://www.bis.org/statistics/breakstables8.pdf.

8 The data on government owned banks has not been updated. Unfortunately, the value of assets held by a bank cannot be split into the nationality of whom it is lent to. In the mentioned statistics, it is assumed that the assets are outstanding in the same country as the country of residence of the bank they belong to.
} 
In turn, this begs the question of whether these banks are simply following MNEs or if they go abroad for similar reasons as non-financial enterprises. Starting with Goldberg and Saunders (1981) the literature has long focused attention on the evidence that banks pursue a 'follow-the-customer' strategy when deciding upon foreign market entry. Goldberg and Grosse (1994) find that banks investing in the US during the 1980s were following their clients. More recent research finds that banks, just like other firms, are sensitive to distance and local market potential in host countries and do not necessarily follow customers (Focarelli and Pozzolo, 2008). Also Buch and Golder (2001) find that banks entering the US market were also engaged in providing other financial services to local and third-country clients. Seth et al. (1998) also report that the majority of loans in banks' portfolios are to non-home country borrowers. Poelhekke (2015) and Ongena et al. (2015) address the issue of who follows who and find that banks, once having entered a foreign market, also predict more investment by non-financial enterprises.

The next section briefly reviews the motives for firms to pursue FDI and highlights the role of transaction costs and links financial globalization and multinational banking to a reduction in transaction costs.

\section{Financial globalization as a reduction in fixed costs}

The decision to engage in foreign direct investment is determined by trade and transaction costs. This section briefly revisits what these costs entail and how they determine FDI, and discusses how financial globalization may affect them. Financial globalization may promote FDI, but at the same time promote trade which in turn could substitute for FDI.

Models of FDI have mostly focussed on the spatial organization between parent firms and affiliates in which local production cost advantages are traded off with transportation costs. For example, if transportation costs are high, making it costly to produce at home and 
ship goods to a foreign market, then firms could save on total costs by setting up secondary production affiliates in their main foreign markets. This predicts so-called horizontal FDI to serve the local market by means of local production instead of costly trade (Markusen, 1984). If on the other hand domestic production cost are significant, but relatively cheaper in foreign markets, then 'vertical' FDI may arise. In this case some or all production of final goods is moved abroad but the final good is shipped back to home market consumers (Helpman, 1984). Mixed models such as export-platform FDI occur if multinationals use horizontal FDI to sell in the host market and in neighboring countries in addition to the home market (Ekholm et al., 2007), while export-fragmentation FDI allows fragmentation of the production process by producing through intermediaries in different countries, and shipping the final good back to the parent or another country (Yeaple, 2003). All of these forms of FDI may be done through 'greenfield' investment where the parent buys land and machines to set up a new plant. However, Neary (2009) notes that mergers and acquisitions of existing plants and firms constitute by far the largest part of the value of foreign direct investment. Consistent with this, Alfaro and Carlton (2009) show that most FDI is of the vertical type where parents seek out specialized suppliers.

The downside of FDI over selling in foreign markets through direct trade is that it requires much higher fixed costs. Combined with the observed heterogeneity in firms' productivity, this provides a sounds basis to explain why relatively few firms export and even fewer undertake FDI. In Helpman et al. (2004), only some very productive firms can overcome these fixed costs to increase profitability. Because each firm has a different level of productivity, firms sort themselves into domestic producers, exporters and those engaging in FDI. $^{9}$

\footnotetext{
${ }^{9}$ Recent theoretical advancements have been made that nuance this view somewhat. Mrázová and Neary (2013) show that it is possible that the most productive firm may have little to gain from engaging in FDI because its trade costs are already very low: paying an additional fixed cost to save on trade costs that are already small may not increase profits anymore. Similarly, very productive firms may have little to gain in terms of wage costs from offshoring to low wage countries, because their wage bill is already low. Empirically this is supported by Yeaple (2009), who shows that there is less evidence for FDI in US data than would be expected from the distribution of productivity among US firms.
} 
What are these fixed costs composed of? Some are no different for domestic producers or exporters, but they can be higher if they concern other markets or countries about which the firm is relatively less knowledgeable. Examples include costs for research and development, meeting product standards, red tape, setting up distribution networks and replacing machinery (Greenaway and Kneller, 2007). Financial constraints will thus also affect the ability of firms to overcome these costs (Manova, 2013). For example, Inui et al. (2015) report that the probability exporting is higher when a Japanese firm is mainly financed by a bank that has many other exporting firms as clients. In addition, a firm wishing to expand abroad faces several decisions which - independent of whether foreign expansion is of the horizontal, vertical or mixed type - involve information asymmetries between the parent and the investment opportunity. Whereas the target firm has insider knowledge on the state of its business, such knowledge is much harder to acquire for an outsider, let alone for an outsider from another country. It cannot easily assess all dimensions of the target firm to successfully judge the investment opportunity. These include for example the financial health of the target, its style of corporate governance and valuation of its assets such as its customer base, buildings and machines, brands, patents, etc. These issues arise in any investment decision, but because in this case investment takes place across borders and at a sometimes large physical and cultural distance, they are arguably of greater importance and potential cost to the parent firm. Moreover, the formal institutions of both home and host countries may be very different and difficult to compare. ${ }^{10}$ This makes it harder to judge investor protection and the scope for legal recourse should the investment turn sour.

It could be that information asymmetries and investor risk are narrowed by detailed industry research performed by the parent firms themselves or by specialized business services. However, financial globalization, through the network of tighter links between banks and their own foreign subsidiaries and branches, may also help to deal with information asymmetry and help to lower the fixed costs of FDI. If these services are (strategic) complements to lending (which still tends to be banks' main source of income) then banks are also likely to supply

\footnotetext{
${ }^{10}$ According to Moxnes (2010), these country-specific costs can be three times as large as general costs.
} 
them. ${ }^{11}$ Moreover, unless the parent firm is awash with cash or the home financial market is deep enough, the acquisitions themselves require loans of sizeable proportions or issuance of corporate bonds, and thus the intermediation by groups of banks. Such syndicated loans and the sale of corporate bonds in multiple markets are also made possible through financial globalization.

Relatively less research has been done on these aspects of foreign direct investment than on its determinants. The empirical evidence that is discussed further down is suggestive of the importance of global financial markets but also far from conclusive. Because many pieces of evidence are rather indirect, more research needs to be done to investigate exactly how strong these links are. With this caveat in mind, financial globalization, and multinational banks in particular, may decrease transaction costs in mainly four ways: increasing the size and quality of the pool of target firms; bridging the institutional distance between parent and affiliate countries; improving internal capital markets; provide financing directly. Before discussing each, we briefly define banks.

Banks are very different from ordinary firms in that they do not combine capital and labor to produce physical goods. They provide capital to firms by collecting (many small) savings and turning them into loans of different sizes and maturities. The capital is provided at different interest rates or not at all, depending on the perceived risk of default on the loans. To minimize default risk, banks have to assess the credit worthiness of their clients, value assets used for collateral, and - especially for large loans - monitor how the loans are used. This means that they specialize in reducing asymmetric information. Banks also provide diversification of risk by selling loans to financial investors which may decrease interest rates and increase the supply of loans. They also offer cross-border payment services and they provide market knowledge and advise. Finally, firms and banks build relationships which are found to increase credit supply because the firm acquires a credit history which is private to its bank (Berger and Udell, 1995). ${ }^{12}$ Multinational banks are more than just holding companies of a collection of otherwise

\footnotetext{
${ }^{11}$ See for example Spence (1976) for a general treatment of the concept of strategic complements.

12 See for a complete treatment Freixas and Rochet (2008) and Degryse et al. (2009). Some evidence for the importance of non-lending services is provided by (Bartoli et al., 2014).
} 
independent banks. They have a strong incentive to operate in an integrated manner by raising funds at the lowest costs in one market and lending it in another market where there is more demand, while exploiting economies of scope and scale across branches and subsidiaries.

Do multinational banks increase the size and quality of the pool of target firms?

There are search costs involved in finding suitable potential subsidiaries. For example, in the model of Grossman and Helpman (2002), some types of asymmetry, such as the degree of contract enforcement and how relationship-specific investments are, determine whether the firm engages in an ownership relationship with the affiliate (offshoring) as opposed to an arm's length relationship (outsourcing). Grossman and Helpman (2005) allow for explicit technology related search costs incurred by the multinational for finding outsourcing partners across countries. Risk of failure makes it worthwhile to find a trustworthy affiliate and because banks lend to firms they can assess the likelihood of financial misconduct.

The banking literature emphasizes the importance of physical proximity between firms and lenders for effective monitoring and collection of soft information (Petersen and Rajan, 1994 and 2002). The alternative of arm's length lending relies mostly on hard information, which is the type of information that is relatively easier to acquire and more accessible for MNEs as well. The idea that distance related agency and informational costs are very substantial is suggested by the fact the even banks face these costs (Mian, 2006). Also Berger et al. (2001) find that South American foreign banks are more likely to lend to small Argentine businesses than foreign banks from other regions. Arguably, these effects should be stronger for MNEs which do not specialize in overcoming agency and informational transaction costs.

Monitoring after investment could be an additional advantage offered by multinational banks. In Antràs et al. (2009) credit constraints, relationship specific investments and weak investor protection create the need to monitor investments, leading to vertical integration if monitoring is done by parent firms. They find for a sample of US multinationals that while the percentage of foreign ownership is indeed decreasing in the level of investor protection, the 
scale of operations is nonetheless increasing in investor protection. ${ }^{13}$ In their model firms are assumed to be better monitors than banks, leading to similar conclusions when banks also monitor investment. However, the model is inconclusive for low levels of protection and unless the firm's activities are very specialized banks may well be better at monitoring. Also information disclosure affects foreign investment. Kroszner et al. (2007) find that the disproportional negative effect that banking crises have on firms that depend on external finance (through the credit channel) is attenuated for less opaque firms with better information disclosure. In Beck (2002) financial intermediation arises due to information asymmetries and financial intermediaries incur search costs when channeling savings to entrepreneurs. Financial development is modelled as lowering the search costs and thus increasing the supply of external finance in the economy. As a provider of capital an MNE faces similar constraints. However, because there is usually no pooling of capital by multiple MNEs and no risk sharing the costs will be higher, making the services provided by financial intermediaries relatively more important.

\section{Do multinational banks aid in bridging institutional distance?}

Multinational banks may help to decrease institutional distance between subsidiaries and MNEs at the country level, where distance can be geographical, cultural, hierarchical and institutional or relate to differences in tax treatment between the destination country and the firm's home country. This channel predicts that banks from the same origin country are more important for foreign investment than similar services offered by either domestic host country banks or other foreign banks, and more so in relatively difficult host countries that suffer from more corruption or weak rule of law. The more involved a foreign bank is in the local market, the easier it will be to bridge these measures of distance. In addition, soft information through banks' direct investment should be more beneficial than hard information collected for cross-

\footnotetext{
${ }^{13}$ Claessens and Laeven (2003) show that the security of property rights has as large an effect on asset allocation and firm growth as financial development does. Lack of property rights induce firms to over-invest in tangible capital which is easier to protect from competitors. Weak contract enforcement also results in under-investment and specialization in products that require less relationship-specific investments (Nunn, 2007).
} 
border lending. Direct evidence for this is provided by Poelhekke (2015). He finds that, between 1984 and 2003, more investment by non-financial Dutch firms is predicted in markets where banks form the same source country have invested in branches and subsidiaries as well. Moreover, the effect appears to be stronger in more opaque markets that have weaker institutions than the home market. These findings are confirmed for China as a destination in Ongena et al. (2015), and for the Shanghai region and the special economic zone of Shenzhen in He and Gray (2001). Also De Bonis et al. (2015) provide suggestive evidence for a small sample of Italian firms that they are more likely to perform FDI if the relationship with their bank is longer and if their bank is multinational as well.

\section{Do multinational banks improve internal capital markets of MNEs?}

The cross-country institutional knowledge that multinational banks acquire may also benefit the internal financial organization of the multinational, which involves optimal capital allocation across affiliates and efficient payment services. Desai et al. (2004) find evidence that the financial organization of multinationals' activities is affected by the depth of local credit markets, especially if creditor rights are weak. Local bankruptcy laws prevail such that local creditor rights matter more in the case of disputes, resulting in higher local interest rates and more expensive funding. Foreign affiliates then depend heavily on the MNE's internal capital market for their financing. For example, they can choose to raise money in other markets than the affiliate's market. Multinational banks which are familiar with the parent firm's operations and local imperfections in external capital markets may be able to help arrange financing within multinationals in the most efficient way and help to raise funding in other financial markets. Manova et al. (2015) find that firms operating in an environment of relatively underdeveloped

local credit markets who can rely on foreign parents for funding, export larger volumes of a broader range of products to more countries. FDI is therefore a more productive organizational structure over arm's length relationships in sectors which depend on external capital or which have fewer collateralizable assets. Similarly, Argentinian firms are more likely to be foreign owned when they depend on external finance (Bustos, 2011). The need for efficient capital 
allocation between subsidiaries in multiple credit markets suggests that there is a role for financial intermediation by multinational banks.

\section{Do multinational banks finance acquisitions directly?}

The final channel works through direct financing of multinationals' foreign operations by banks. For example, Klein et al. (2002) show that firms initiate fewer FDI projects if their home bank is in distress. This suggests that even the very productive multination firms rely at least partially on banks to finance their acquisitions. However, it also implies that financial shocks may have real global repercussions through globalized financial markets and their effects on the investment decisions of multinational firms. The largest (multinational) firms may be able to raise capital on the corporate bond markets themselves. Section 5 will explore the effects of the recent financial crisis on FDI.

Overall, banking globalization may help to level information asymmetries and thereby reduce the fixed costs of engaging in FDI. Lower fixed costs imply that more firms are able to become multinationals and that global value chains may spread to more markets and foreign destinations. The next section explores whether financial globalization may also reduce the costs and risks of trading, which may reduce the need to vertically integrate suppliers and thus could reduce FDI.

\section{Financial globalization as a reduction in trade costs}

Models of FDI trade off the cost reduction of forgone trade costs with the fixed costs of engaging in FDI. A recent literature has started to look at the relation between financial globalization and trade and finds that it may decrease trade costs. This also implies that if 
financial globalization affects both trade costs and the fixed costs, then the former effect may decrease the motive for vertical integration across borders, but it depends on which effect dominates. Central in this argument is that banks are providers of trade credit, which reduces the risk of trading.

Antras and Foley (2016) estimate that out of all US sales abroad, most transaction are based on paying cash in advance or through an open account. ${ }^{14} 17 \%$ of the value of transactions involve direct financial intermediation, but this increases to $29 \%$ for new customers, for which risk is higher due to information asymmetry. The risk is that an exporter does not deliver goods as specified in the contract, or that an importer does not pay for goods received. Such intermediation may take the form of a letter of credit, in which a local bank commits to pay for goods on behalf of the importer, before goods are shipped, and a bank in the exporter's country typically commits to paying if the issuing local bank defaults. They find that transactions more often require cash in advance or letter of credit when the importer's country is characterized by weak rule of law or is far away. In that case local banks in importing countries can be used by the exporter, through the letter of credit, to pursue financial claims against defaulting importers.

Niepmann and Schmidt-Eisenlohr (2016), who estimate that 12.5 percent of World trade involves letters of credit in 2012, show the importance of multinational banking for the availability of letters of credit. They find that reductions in the supply of letters of credit by banks decrease U.S. exports and that the effect is stronger for destination countries where fewer U.S. banks are active. The reason is that letters of credit need to be issued by a local bank and confirmed by the exporter's bank, something that entails high fixed cost among banks and is more easily done within one multinational bank. Moreover, banks learn about the creditworthiness of their clients, and this information is not easily transferable, and they specialize in particular destination markets. In other words, the more banks are global, the easier it is to secure letters of credit and the easier it is to trade between countries among

\footnotetext{
${ }^{14}$ We focus here on intermediated trade credit. Un-intermediated trade credit, such as paying cash in advance or an open account, may arise if sellers have a cost advantage over banks in the acquisition of information about buyers, or it may serve as a signal of product quality, or as a way to tie buyers to specific suppliers. See Love (2012) for a survey of these and other rationales for trade credit.
} 
which a bank is active. This notion is supported by Caballero et al. (2016) who document that an increase in bank linkages between countries is associated with larger bilateral exports, conjecturing that banks mitigate export risk.

Other ways in which banks affect trade are more indirect through the overall provision of credit and show that the health of banks is related to the volume of exports of their clients. Amiti and Weinstein (2011) show that Japanese banks that experienced a negative shock to their market-to-book value have seen their clients subsequently decrease exports more than domestic sales. Paravisini et al. (2014) show for a sample of Peruvian banks that when they suffer a foreign funding shock their clients have less access to working capital and reduce exports. Ahn (2013), using Colombian data, finds that a shock to bank balance-sheets directly affects the supply of letters of credit. Also Van der Veer (2015) finds a positive and statistically significant effect of private export credit insurance on aggregate exports.

The implication of these findings is that financial globalization, especially in the form of more global banks, reduces the risk and costs of trading. In turn, following the logic of the model by Grossman and Helpman (2002), this means that firms have a reduced incentive to vertically integrate suppliers which may reduce FDI and the associated productivity benefits. However, the effect on trade costs may be smaller than the effect on fixed costs given that intermediated trade credit is used in a minority of transactions. Which effect dominates is ultimately an empirical question.

\section{The effect of the recent financial crisis}

Financial globalization in the form of better access to credit also opens up the risk of the propagation of shocks. If a (foreign) bank is in distress, and more so if the bank if systemic, it may reduce the supply of credit. The integrated manner in which multinational banks operate, result in a diversified response of banks to a liquidity shortage in one of its markets. It can 
compensate by drawing on any of its other markets - and thus reducing the supply of credit there - to restore liquidity where it is needed. For example, the 1998 Russian default led to reduced bank-to-bank lending to Peruvian banks such that Peruvian banks reduced lending to Peruvian firms (Schnabl, 2012). Also Hale et al. (2016) find for a large set of countries that direct exposure of banks to crisis countries squeezes their profit margins (although indirect exposure (via other banks that they lend to) to non-crisis countries mitigates it). As a result, crisis exposure has real effects in that they reduce banks' supply of domestic and cross-border loans.

Did the crisis lead to a reversal of the globalization of banks? If so, it would reduce the collateral benefits of multinational banking for financial sector development and FDI as well. The degree of regulation that has tightened during and in the aftermath of the crisis has so far not led to the outright closure of markets to foreign banks. Instead, the risk of cross-border contagion has led to the development of better supervision and resolution mechanisms for failing banks (such as the banking union for large banks in the EU) but mostly to more prudential regulation. The latter is important because in all cases outside the banking union national supervisory authorities take precedence. Apart from issues of sovereignty it is inherently difficult to deal with failing multinational banks because the value of assets is hard to monitor which could delay intervention, without so called 'living-wills' it is hard to separate the cross-exposures of all subsidiaries, and any intervention has to be coordinated across potentially many countries. Prudential regulation has taken the form of tighter capital adequacy ratios such as through the new Basel Committee accord. To reduce the issue of banks being 'too-big-to-fail', macroprudential policy is still taking form such as a call for more standardized derivative contracts, or trying to fight bubbles in specific markets by, for example, tightening mortgage lending rules (Galati and Moessner, 2013).

The banking sector itself has also responded to the crisis by reducing cross-border exposures due to banks' sensitivity to perceived risk (Milesi-Ferretti and Tille, 2011). Banks on the other hand have not uniformly decreased their foreign presence in the form of banking FDI. Banks from OECD countries for example now represent a smaller share of aggregate foreign bank assets, but banks from non-OECD countries have entered foreign markets in their own region. Banks that were especially hit hard by the global crisis were more likely to sell foreign 
operations (Claessens and Van Horen, 2015). This may have been the result of tighter capital requirements (and the need to raise more capital), or under pressure from governments who supported these banks or because they became direct owners after rescue operations.

If the crisis has also reduced trade credit and increased the risk and cost associated with trade across borders, it may have boosted FDI as a motive to reduce trade costs. Firms that make use of trade credit may then also reduce trade financing to their customers and propagate the shock up the supply chain. Evidence for such a chain of events is provided by Love et al. (2007): firms with high short-term debt reduce their provision of trade credit relatively more after an aggregate credit crunch. In fact, firms with more access to outside finance might be hurt more (Boissay and Gropp, 2013). In January 2009 - months after the Lehman default - the drop in trade was 30\% according to Malouche (2009). Ahn et al. (2011) showed that the lack of trade finance during 2008-2009 contributed to the 'great trade collapse', and also Chor and Manova (2012) argue that adverse credit conditions were the main reason behind the trade collapse. Data in Hale et al. (2016) show that the network of multinational banks has not yet returned to pre-crisis levels by 2012. The number of syndicated loans to banks and to firms is still lower, banks' profitability is much lower, and the density of the network between banks (defined as the number of observed connections in the network divided by the total number of possible connections) has not returned to the pre-crisis levels. This is important, because Caballero et al. (2016) show that this network reduces information asymmetry between banks which in turn stimulates trade credit and exports. The crisis may thus have reduced trade, notably exports to more opaque non-OECD markets and for less homogenous goods where trade disputes are more likely. In the latter case, vertical production chains may have to rely on FDI as a substitute for trade to ensure prompt payment, delivery, and high product quality. Consistent with this, FDI flows have been much more resilient than other capital flows and the trade of goods. 


\section{Conclusion}

The deregulation of the financial system and the banking sector in particular facilitated the internationalization of banking. The lower costs of operating across borders allowed more banks to become multinational in much the same way as only the most productive nonfinancial firms are able to compete on world markets. Multinational banking, however, appears to come with significant positive - and potential negative - effects on both their host economies and on other non-financial multinational enterprises. On the positive side, foreign banks increase the supply of external financing available at lower costs, introduce more diverse financial instruments, and higher quality financial services allow for better financial intermediation and risk diversification. Moreover, multinational banking appears to have led to a reduction in broadly defined transaction costs related to the foreign activities of non-financial firms. This can boost both trade through the provision of trade finance, and foreign direct investment through a reduction in the fixed costs and risk of investing abroad. On the negative side, the recent global crisis showed how host economies and firms have become more exposed to external financial shocks. These can be propagated through international financial links, among which the network of foreign banks and their subsidiaries. So far, the response of governments to the recent global crisis has not been to reverse the trend in banking sector liberalization back to the high levels of regulation of the 1980s. Although regulation has increased somewhat, most of the focus has been on improved supervision and better resolution mechanisms to deal with future crises. To preserve the benefits of multinational banking for the real economy and for non-financial FDI, regulators should aim to curtail the risks of contagion while making sure to retain the benefits. 


\section{References}

Abiad, A., E. Detragiache and T. Tressel (2010). A New Database of Financial Reforms, IMF Staff Papers 57(2), 281-302.

Ahn, J, (2013). Estimating the Direct Impact of Bank Liquidity Shocks on the Real Economy: Evidence from Letter-of-Credit Import Transactions in Colombia", mimeo, May 2013.

JaeBin Ahn \& Mary Amiti \& David E. Weinstein, 2011. "Trade Finance and the Great Trade Collapse," American Economic Review, American Economic Association, vol. 101(3), pages 298-302, May.

Alfaro, Laura and Andrew Carlton. 2009. "Intra-industry Foreign Direct Investment." American Economic Review, 99(5): 2096-2119.

Alfaro, L., Chanda, A., Kalemli-Ozcan, S., Sayek, S., 2004. FDI and economic growth: the role of local financial markets. Journal of International Economics 64, 89-112.

Mary Amiti \& David E. Weinstein, 2011. "Exports and Financial Shocks," The Quarterly Journal of Economics, Oxford University Press, vol. 126(4), pages 1841-1877.

Antràs, P., M. Desai and F. Foley (2009). Multinational Firms, FDI Flows and Imperfect Capital Markets, Quarterly Journal of Economics 124(3), 1171-219.

Antràs, Pol and C. Fritz Foley, (2016) "Poultry in Motion: A Study of International Trade Finance Practices," Journal of Political Economy, forthcoming.

Jean Arcand \& Enrico Berkes \& Ugo Panizza, 2015. "Too much finance?," Journal of Economic Growth, Springer, vol. 20(2), pages 105-148, June.

Bartoli F, Ferri G, Murro P, Rotondi Z. Bank support and export: evidence from small Italian firms. SmallBusEcon2014;42(2): 245-64.

Beck, T. (2002). Financial Development and International Trade. Is There a Link?, Journal of International Economics 57, 107-131.

Berger, A.N., L.F. Klapper, and G.F. Udell (2001). The ability of banks to lend informationally opaque small businesses, Journal of Banking and Finance 25, 2127-2167.

Frederic Boissay \& Reint Gropp, 2013. "Payment Defaults and Interfirm Liquidity Provision," Review of Finance, European Finance Association, vol. 17(6), pages 1853-1894.

Riccardo De Bonis, Giovanni Ferri, Zeno Rotondi, Do firm-bank relationships affect firms' internationalization? International Economics, Volume 142, August 2015, Pages 60-80

Borensztein, E., De Gregório, J., Lee, J.-W., 1998. How does foreign direct investment affect economic growth? Journal of International Economics 45, 115-135.

Buch, C. M. and S. M. Golder, 2001, "Foreign versus domestic banks in Germany and the U.S.: A tale of two markets?" Journal of Multinational Financial Management, Vol. 11, No. 4, pp. 341-61.

Claudia M. Buch, Cathérine T. Koch, Michael Koetter. 2011. Size, productivity, and international banking, Journal of International Economics 85 (2011) 329-334.

Buch, C.M. and A. Lipponer (2007). FDI versus exports: Evidence from German banks. Journal of Banking \& Finance 31, 805-826.

Bustos, P. (2011). Trade Liberalization, Exports and Technology Upgrading: Evidence on the impact of MERCOSUR on Argentinian Firms, American Economic Review 101(1), 304340. 
Caballero, J., C. Candelaria and G. Hale. (2016). Bank Linkages and International Trade. Federal Reserve Bank of San Francisco Working Paper 2013-14, February 2016.

Gerard Caprio (Editor), The Evidence and Impact of Financial Globalization, Academic Press 2012, pp 800.

Cerutti, E., Dell'Ariccia, G., Martínez Pería, M.S., 2007. How banks go abroad: branches or subsidiaries? Journal of Banking and Finance 31, 1669-1692.

Menzie D. Chinn, Barry Eichengreen and Hiro Ito. A forensic analysis of global imbalances. Oxf. Econ. Pap. (2014) 66 (2): 465-490.

Chor, Davin \& Manova, Kalina, 2012. "Off the cliff and back? Credit conditions and international trade during the global financial crisis," Journal of International Economics, Elsevier, vol. 87(1), pages 117-133.

Stijn Claessens and Neeltje van Horen. 2015. The Impact of the Global Financial Crisis on Banking Globalization, IMF Economic Review 63(4 868-918.

Coeurdacier, Nicolas and Hélène Rey, "Home Bias in Open Economy Financial Macroeconomics", Journal of Economic Literature 2012, 51(1), 63-115.

Cull, Robert \& Soledad Martinez Peria, Maria, 2010. "Foreign bank participation in developing countries : what do we know about the drivers and consequences of this phenomenon?," Policy Research Working Paper Series 5398, The World Bank.

Riccardo De Bonis \& Giovanni Ferri \& Zeno Rotondi, 2015. "Do firm-bank relationships affect firms' internationalization?," International Economics, CEPII research center, issue 142, pages 60-80.

Augusto de la Torre \& Juan Carlos Gozzi \& Sergio L. Schmukler, 2008. "Capital Market Development: Whither Latin America?," NBER Chapters, in: Financial Markets Volatility and Performance in Emerging Markets, pages 121-154 National Bureau of Economic Research, Inc.

Hans Degryse, Moshe Kim, Steven Ongena. Microeconometrics of Banking: Methods, Applications, and Results 1st Edition 2009 pp256

Degryse, H., Ongena, S., 2005. Distance, lending relationships, and competition. Journal of Finance 60, 231-266.

Desai, M., F. Foley and J. Hines (2004). A Multinational Perspective on Capital Structure Choice and Internal Capital Markets, Journal of Finance 59, 2451-2488.

Ekholm, K., R. Forslid and J.R. Markusen (2007). Export-platform foreign direct investment, Journal of the European Economic Association 5(4), 776-795.

Focarelli, D. and A. F. Pozzolo, 2005, "Where do banks expand abroad? An empirical analysis," Journal of Business, Vol. 78, No. 6, pp. 2435-64.

Xavier Freixas and Jean-Charles Rochet, Microeconomics of Banking (MIT Press) second edition Edition, 2008.pp392

Gabriele Galati and Richhild Moessner. 2013. Macroprudential policy - a literature review, Journal of Economic Surveys, Volume 27, Issue 5, Pages 846-878

Goldberg, L.G., Grosse, R. (1994). Location choice of foreign bank in the United States. Journal of Economics and Business 46(5), 367-379.

Goldberg, L. G. and A. Saunders, 1981, "The determinants of foreign banking activity in the United States," Journal of Banking and Finance, Vol. 5, No. 1, pp. 17-32. 
Goldberg, L.S. (2009). Understanding Banking Sector Globalization, IMF Staff Papers 56, 171197.

Greenaway D, Kneller R. Firm heterogeneity, exporting and foreign direct investment. EconJ2007;117:134-61.

Grossman, G.M. and E. Helpman (2002). Integration versus Outsourcing in Industry Equilibrium, Quarterly Journal of Economics 117, 85-120.

Grossman, G.M. and E. Helpman (2005). Outsourcing in a global economy, Review of Economic Studies 72, 135-159.

Guadalupe, Maria, Olga Kuzmina and Catherine Thomas (2012). "Innovation and Foreign Ownership." American Economic Review, 102(7), 3594-362.

Hale, G. (2012). "Bank relationships, business cycles, and financial crises," Journal of International Economics, Elsevier, vol. 88(2), pages 312-325.

Hale, Galina, Tumer Kapan, Camelia Minoiu. 2016. “Crisis Transmission through the Global Banking Network." Federal Reserve Bank of San Francisco Working Paper 2016-01.

He Q, Gray HP. Multinational banking and economic development: a case study. J Asian Econ 2001;12:233-43.

Helpman, E. (1984). A Simple Theory of International Trade with Multinational Corporations. Journal of Political Economy, 92, (3), 451-71

Helpman, E., M.J. Melitz and S.R. Yeaple (2004). Export versus FDI with heterogeneous firms, American Economic Review 94, 300-316.

Herrera AM, MinettiR. Informed finance and technological change: evidence from credit relationships. JFinancEcon2007;83: 223-69.

Inui, T., Ito, K., and Miyakawa, D. (2015) “Overseas market information and firms' export decisions," Economic Inquiry 53(3), 1671-1688.

Javorcik, B.S., 2004. Does foreign direct investment increase the productivity of domestic firms? in search of spillovers through backward linkages. American Economic Review 94, 605627.

Javorcik, Beata, and Steven Poelhekke (2016). "Former Foreign Affiliates: Cast Out and Outperformed?" Journal of the European Economic Association, forthcoming.

Beata S. Javorcik and Mariana Spatareanu 2009. Liquidity Constraints and Firms' Linkages with Multinationals, World Bank Economic Review 23(2) Pp. 323-346.

Klein, M.W., J. Peek and E.S. Rosengren (2002). Troubled Banks, Impaired Foreign Direct Investment: The Role of Relative Access to Credit, American Economic Review 92(3), 664-682.

Kose, M.A., E.S. Prasad, K. Rogoff and S-J. Wei (2009). Financial globalization: a reappraisal, IMF Staff Papers 56(1), 8-62.

Kroszner, Randall S. \& Laeven, Luc \& Klingebiel, Daniela, 2007. "Banking crises, financial dependence, and growth," Journal of Financial Economics, Elsevier, vol. 84(1), pages 187-228, April.

Lane, P., Milesi-Ferretti, G.M., 2007. The external wealth of nations mark II: revised and extended estimates of foreign assets and liabilities, 1970-2004. Journal of International Economics 73, 223-250. 
Levine, Ross, 2005. "Finance and Growth: Theory and Evidence," Handbook of Economic Growth, in: Philippe Aghion \& Steven Durlauf (ed.), Handbook of Economic Growth, edition 1, volume 1, chapter 12, pages 865-934 Elsevier.

Love, Preve, Sarria-Allende, 2007 Trade credit and bank credit: evidence from recent financial crisis, Journal of Financial Economics, 83 (2007), pp. 453-469.

Love, I. (2012). Role of Trade Finance, Chpter 13 in: Gerard Caprio (Editor), The Evidence and Impact of Financial Globalization, Academic Press 2012, pp 800.

Mariem Malouche (2009). Trade And Trade Finance Developments In 14 Developing Countries Post September 2008 - A World Bank Survey. Policy Research Working Papers.

Manova K. (2013). Credit constraints, heterogeneous firms, and international trade. Rev Econ Stud 2013;80(3):711-44.

Kalina Manova \& Shang-Jin Wei \& Zhiwei Zhang, 2015. "Firm Exports and Multinational Activity Under Credit Constraints," The Review of Economics and Statistics, MIT Press, vol. 97(3), pages 574-588, July.

Markusen, J.R. (1984). Multinationals, multi-plant economies, and the gains from trade, Journal of International Economics 16(3-4), 205-226.

McGuire, P., Tarashev, N., 2008. Global Monitoring with the BIS International Banking Statistics, BIS Working Paper 244.

Mian, A. (2006). Distance Constraints: The Limits of Foreign Lending in Poor Economies, Journal of Finance 61(3), 1465-1505.

Micco, A., U. Panizza, and M. Yanez Pagans, (2007). Bank ownership and performance. Does politics matter?, Journal of Banking \& Finance 31(1), 219-241.

Milesi-Ferretti, G.M., Tille, C., 2011. The great retrenchment: international capital flows during the global financial crisis. Economic Policy 26 (66), 289-346.

Moxnes A. Are sunk costs in exporting country-specific? Can J Econ 2010;43(2):467-93.

Mrázová, Monika and J. Peter Neary (2013). "Selection Effects with Heterogeneous Firms." University of Oxford, mimeo.

Neary, J.P. (2009). Trade costs and foreign direct investment, International Review of Economics and Finance 18, 207-218.

Niepmann, Friederike and Tim Schmidt-Eisenlohr (2016). No Guarantees, No Trade: How Banks Affect Export Patterns. International Finance Discussion Papers 1158.

Obstfeld, M., 2009. International finance and growth in developing countries: what have we learned? IMF Staff Papers 56, 63-111.

Steven Ongena, Shusen Qi, Fengming Qin, Impact of Foreign Bank Presence on Foreign Direct Investment in China, China \& World Economy / 40-59, Vol. 23, No. 4, 2015

Paravisini, D., V. Rappoport, P. Schnabl, and D. Wolfenzon. (2014). Dissecting the Effect of Credit Supply on Trade: Evidence from Matched Credit-Export Data, Review of Economic Studies, 82(1), 333-359.

Petersen, M.A. and R. Rajan (1994). The benefits of firm-creditor relationships: Evidence from small-business data, Journal of Finance 49, 3-37.

Petersen, M.A. and R. Rajan (2002). Does distance still matter? The information revolution in small business lending, Journal of Finance 57, 2533-2570.

Poelhekke, Steven (2015). "Do global banks facilitate foreign direct investment?", European Economic Review 76, 25-46. 
Rajan, R. and L. Zingales (1998). Financial Dependence and Growth, American Economic Review 88, 559-86.

ANDREW K. ROSE and TOMASZ WIELADEK (2014). Financial Protectionism? First Evidence, THE JOURNAL OF FINANCE • VOL. LXIX, NO. 5, 2127-2149.

Seth, R., D.E. Nolle, and S.K. Mohanty, 1998, "Do Banks Follow their Customers Abroad?," Financial Markets, Institutions, and Instruments 7, 1-25.

Schnabl, P. 2012. The International Transmission of Bank Liquidity Shocks: Evidence from an Emerging Market. Journal of Finance, 67(3), June 2012, 897-932

Spence, A.M. (1976). Product Selection, Fixed Costs, and Monopolistic Competition, The Review of Economic Studies 43(2), 217-235.

Strahan P. 2013. Too Big to Fail: Causes, Consequences, and Policy Responses, Annual Review of Financial Economics, Vol. 5: 43-61.

Van der Veer, Koen, (2015). "The Private Credit Insurance Effect on Trade," Journal of Risk and Insurance, Vol. 82, No. 3, 601-624 (2015).

Yeaple, S.R. (2003). The complex integration strategies of multinational firms and cross-country dependencies in the structure of foreign direct investment, Journal of International Econoimcs 60, 293-314.

Yeaple, Stephen R. (2009). "Firm Heterogeneity and the Structure of US Multinational Activity." Journal of International Economics, 78(2), 206-215. 